\title{
ECONOMIC ANALYSIS FOR TECHNICAL AND EXECUTIVE PROJECTS WITH GEOSYNTHETIC MATERIALS FOR THE PROTECTION OF LINEAR STRUCTURES IN THE MINING AREAS
}

\author{
Marta Kadela', Monika Gwóźdź-Lasoń2® \\ ${ }^{1}$ Building Research Institute (ITB), Warsaw, Poland \\ ${ }^{2}$ Faculty of Materials, Civil and Environmental Engineering, University of Bielsko-Biala, Bielsko-Biała, Poland
}

\begin{abstract}
This paper discusses the design, execution and economic aspect of building investments such as roads located in mining impact areas. The main identified variables include material items, road investment structure safety and economic analysis of the proposed solutions. Details of design guidelines, including geo-synthetic materials, are presented which meet the initial assumptions for a road structure, such as relevant interaction with adverse mining impact of the subsoil. The presented structure protection and reinforcement solutions are analysed for mining areas of Categories II, III and IV. The expected knowledge of the road structure use and the forecasted mining impact based on material guidelines concerning technical use of each group of geo-synthetics provides a computational model of the whole investment cost, discussed in the paper. The nature of the issue is interdisciplinary, and includes the aspects of geo-synthetic materials technology, road structure design, geotechnical analysis, stochastic processes, econometrics and reliable source data to forecast the operating impact of mines on the analysed urbanised transport areas.
\end{abstract}

Key words: protection cost, geo-mattress, mining area, road pavement

\section{INTRODUCTION}

Transport infrastructure facilities are an important area of investment activity in mining and post-mining areas (Kadela, 2013; Kadela \& Chomacki, 2014). This implies specific problems in the field of mining and building prevention (Gwozdz-Lason, 2017a, 2019a). The threat to the safety status of a building object on mining ground is generally due to the forced displacement and deformation of the subsoil (Fig. 1).

Therefore, it is important to choose the right method of analysis to reliably assess the behavior of the considered object in all anticipated phases of its work (Fedorowicz, 2006; Fedorowicz, Fedorowicz \& Kadela, 2011; Fedorowicz \& Kadela, 2012). At the same time, the designed protection is subjected to assessment which should ensure the safe and trouble-free operation of the protected structure at mining deformations not exceeding a certain value (Kadela $\&$ Bednarski, 2014). All of the above activities are preceded by an assessment of the subsoil load capacity, in natural state or after strengthening. Currently, geo-textile materials are increasingly applied to protect linear engineering investments against mining impacts (continuous and/or discontinuous) of various scales (Kawalec \& Gryczmański, 2009; Grygierek \& Kawalec, 2017; Gwóźdź-Lasoń, 2019). Geo-synthetic solutions are also recommended for the reinforcement of various types of soils subjected to mining impacts according to the regulation (Generalna 


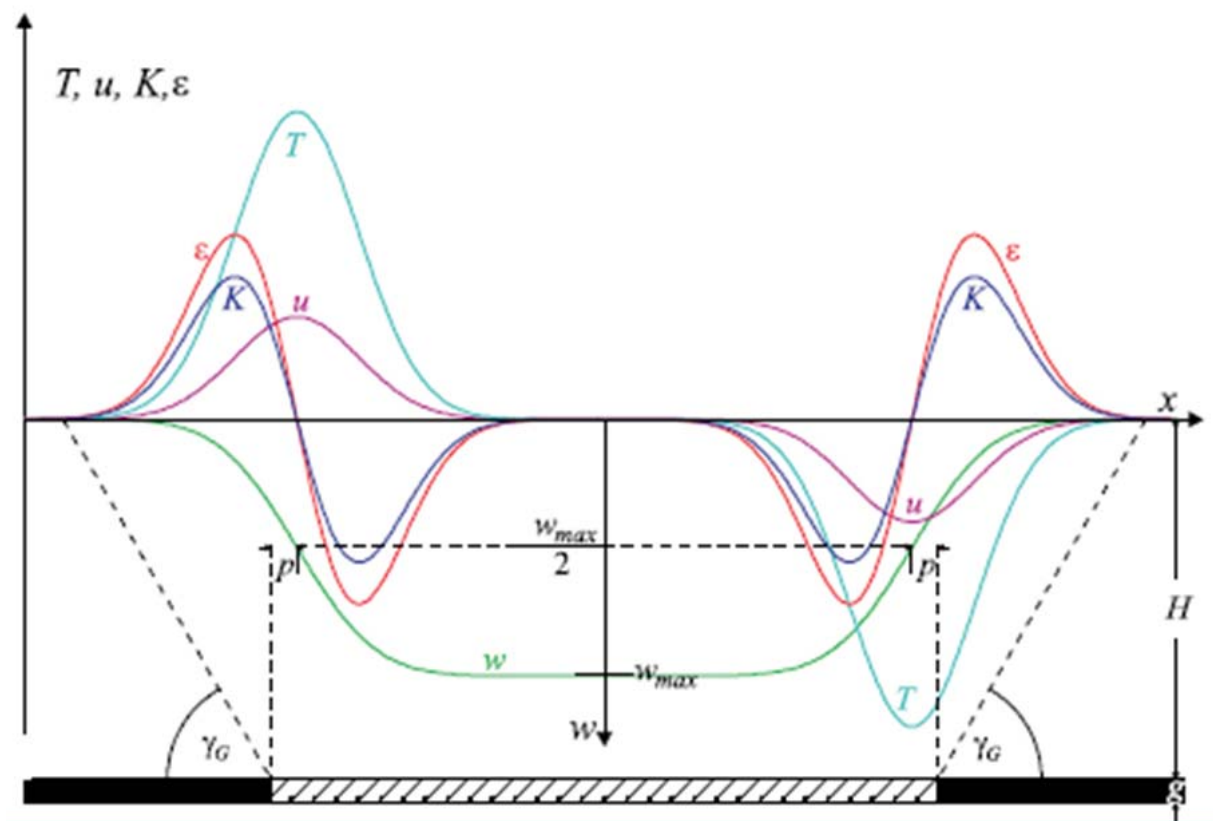

Fig. 1. Scheme of deformation of surface under an exploited coal seam (Kwiatek, 1997)

Dyrekcja Dróg Publicznych, 2002; Instytut Badawczy Dróg i Mostów, 2003). Fedorowicz and Fedorowicz presented the problem of mining impact on the behavior of soil (Fedorowicz, 2008; Fedorowicz \& Fedorowicz, 2012; Fedorowicz \& Kadela, 2017). The building construction-mining subsoil system and their elements were presented for example by Kadela and Chomacki (2013), Dudek, Kadela and Knap (2015), Dudek and Kadela (2016), Kadela, Bartoszek and
Fedorowicz (2017) and Kadela and Chomacki (2017). One way of the protection of pavement structures in mining-affected areas are geo-mattress Generalna Dyrekcja Dróg Publicznych and Instytut Badawczy Dróg i Mostów (2012). It is the most popular way of the protection of linear structures. The geo-mattresses were used in A1 and A4 motorway structure and the other linear structures (Kawalec, Grygierek, Koda \& Osiński, 2019). Figure 2a shows protections a

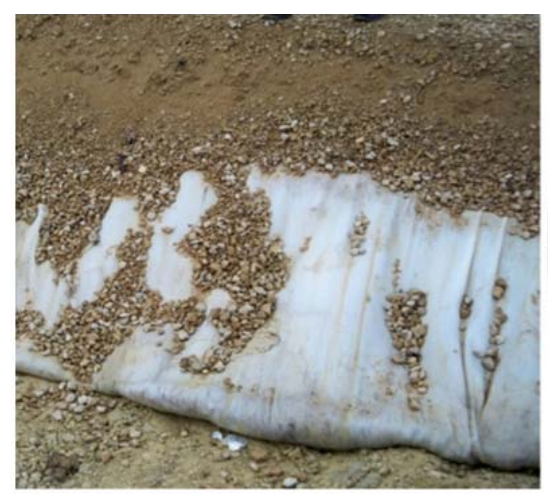

b

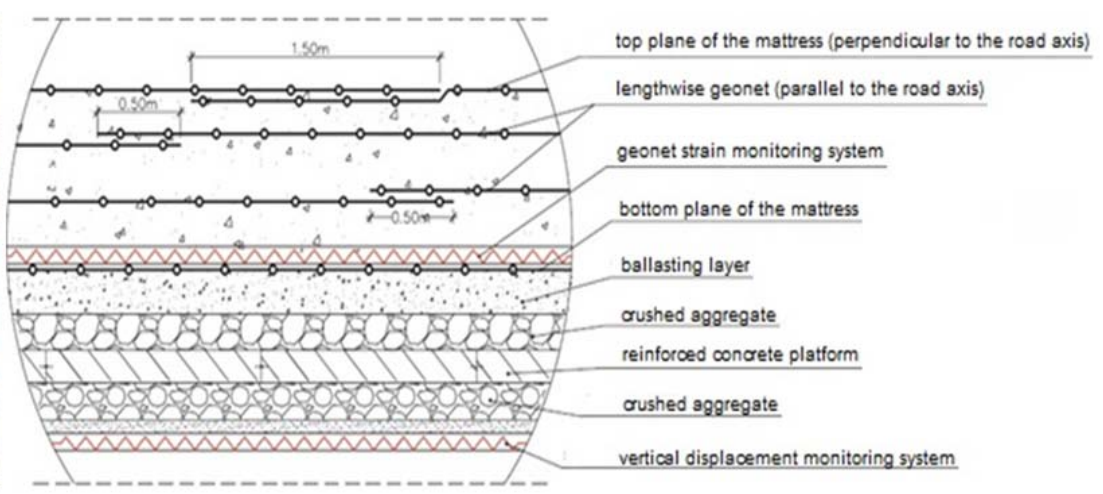

Fig. 2. The geo-mattress on the motorway A1 (photo by J. Fedorowicz) (a); cross-section of the pavement structure of motorway A1 (Sieńko, 2011) (b) 
of the road pavement structure of the A1 motorway in Piekary Śląskie. A reinforced concrete layer has been integrated in the lower layers to minimise the impact of discontinuous deformations in the area (Miłkowski, Pilecki, Kłosek \& Tondera, 2010; Sieńko, 2011).

In the discussed issue, the results of an innovative technology of monitoring of the analysed deformations and loads using fiber Bragg grating (FBG) are increasingly available (Juraszek, 2019, 2020). The risk analysis of building structures (Myrczek, Juraszek \& Tworek, 2020) is one of the attributes influencing the estimated market and replacement value of a construction investment (Wu, Pai \& Hosking, 1996; Gwozdz-Lason, 2019b, 2017b). This way of pavement structure protection implies a high cost (Gwóźdź-Lasoń, 2009; Gwozdz-Lason 2010, 2017a). The aim of this work was an assessment of the cost of the used geo-mattress in dependence on the category of mining area. This problem is an important from an economic and structural point of view for designers and constructors.

\section{MATERIAL AND METHODS}

\section{Analysed protection of the road pavement against mining impacts}

A subsoil improvement applied in the area of the A4 highway in Mysłowice was analysed. The table presents the assumed sequence of layers of pavement structures for planned traffic load categories (KR4 and KR2) (EKKOM Sp. z o.o., 2014). In order to protect the road pavement against deformations resulting from the mining exploitation, the geo-mattresses and geo-synthetic semi-mattresses were used (in the sub-base layer).

Depending on the category of the mining area in the area through which the road passes, reinforcements of different strengths of inserts were used (EKKOM Sp. z o.o., 2014):

a) Reinforcement for mining area of Category II:

- reinforcement of asphalt layers, with geo-composite (net + geo-textile) with a minimum strength of $50 / 50 \mathrm{kN} \cdot \mathrm{m}^{-1}$,

- $30 \mathrm{~cm}$ semi-mattress made of a geo-net with long-term strength of minimum $65 / 65 \mathrm{kN} \cdot \mathrm{m}^{-1}$ with filling of crushed stone aggregate, size $0 / 63 \mathrm{~mm}$, mechanically compacted,

- $20-25 \mathrm{~cm}$ drainage layer of $31.5 / 63 \mathrm{~mm}$ gravel on a separation geo-textile;

b) Reinforcement for mining area of Category III:

- reinforcement of asphalt layers with geo-composite (net + geo-textile) with a minimum strength of $50 / 50 \mathrm{kN} \cdot \mathrm{m}^{-1}$,

- $30 \mathrm{~cm}$ mattress made of a geo-net with long-term strength of minimum $65 / 65 \mathrm{kN} \cdot \mathrm{m}^{-1}$ with filling of crushed stone aggregate, size $0 / 63 \mathrm{~mm}$, mechanically compacted,

- 20-25 cm drainage layer of 31.5/63 mm crushed stone aggregate on a separation geo-textile;

c) Reinforcement for mining area of Category IV:

- reinforcement of asphalt layers with geo-composite (net + geo-textile) with a minimum strength of $50 / 50 \mathrm{kN} \cdot \mathrm{m}^{-1}$,

Table. The assumed sequence of layers of pavement structures (EKKOM Sp. z o.o., 2014)

\begin{tabular}{|c|c|c|c|}
\hline $\begin{array}{l}\text { Category of } \\
\text { traffic load }\end{array}$ & $\begin{array}{l}\text { Thickness } \\
{[\mathrm{cm}]}\end{array}$ & Type of layer & Material of layer \\
\hline \multirow{4}{*}{ KR4 } & 4 & wearing course & SMA mix \\
\hline & 8 & binder course & asphalt concrete AC WMS $16 \mathrm{~W}$ \\
\hline & 11 & base course & asphalt concrete AC $22 \mathrm{P}$ \\
\hline & 20 & auxiliary sub-base & $0 / 31.5 \mathrm{~mm}$ crushed aggregate \\
\hline \multirow{4}{*}{ KR2 } & 5 & wearing course & asphalt concrete AC 11S \\
\hline & 15 & base course & $0 / 31.5 \mathrm{~mm}$ crushed aggregate \\
\hline & 25 & sub-base & 0/63.0 $\mathrm{mm}$ crushed aggregate \\
\hline & 50 & top layer of the embankment & soil with $d>8 \mathrm{~m} / \mathrm{d}$ and $C B R>25 \%$ \\
\hline
\end{tabular}


Kadela, M., Gwóźdź-Lasoń, M. (2021). Economic analysis for technical and executive projects with geosynthetic materials for the protection of linear structures in the mining areas. Acta Sci. Pol. Architectura, 20 (1), 39-49. doi: 10.22630/ASPA.2021.20.1.5

- $30 \mathrm{~cm}$ mattress made of a geo-net with longterm strength of minimum $80 / 80 \mathrm{kN} \cdot \mathrm{m}^{-1}$ with filling of crushed stone aggregate, size $0 / 63 \mathrm{~mm}$, mechanically compacted $20-25 \mathrm{~cm}$ drainage layer of $31.5 / 63 \mathrm{~mm}$ crushed stone aggregate on a $0.2 \mathrm{~m}$ thick separation geo-textile.

\section{Reference investment valuation method}

An economic analysis of the reference building investment is based on various processes of real estate valuation with statistic and econometric models, in the aspect of the residual method. The methodologies are described and analysed in several papers (McParland, Adair \& Mcgreal, 2002; Gwóźdź-Lasoń, 2009, 2010; Gwozdz-Lason, 2017a, 2019c). When analysing the project variables in the comparative approach, all attributes which determine the investment typology and scope, are identified Figure 3. It is important to specify the relevant computational model with any known weight of each market attribute that which affects the investment cost. The expanding data collections enable a statistical and classical analysis to verify the value of the variables entered in the main computational model of the total road investment cost in the assumed period. In the developed $\mathrm{X}_{\mathrm{IB}}$ matrix characterising the analysed group of investments related to transport parcel of property land with a specific group of road structures, the tested features were recorded based on the collection of similar investments and investments updated with the identified time trend, as a mean of the charge values in each quarter of the analysed 24-month period. The variables in the matrix are the source data to estimate the investment values in the aspect of materials, implementation method and investment risk for the designed engineering structure life during mining exploitation in the studied area (Gwóźdź-Lasoń, 2016a, 2016b, Gwozdz-Lason 2017a, 2017b, 2019a).

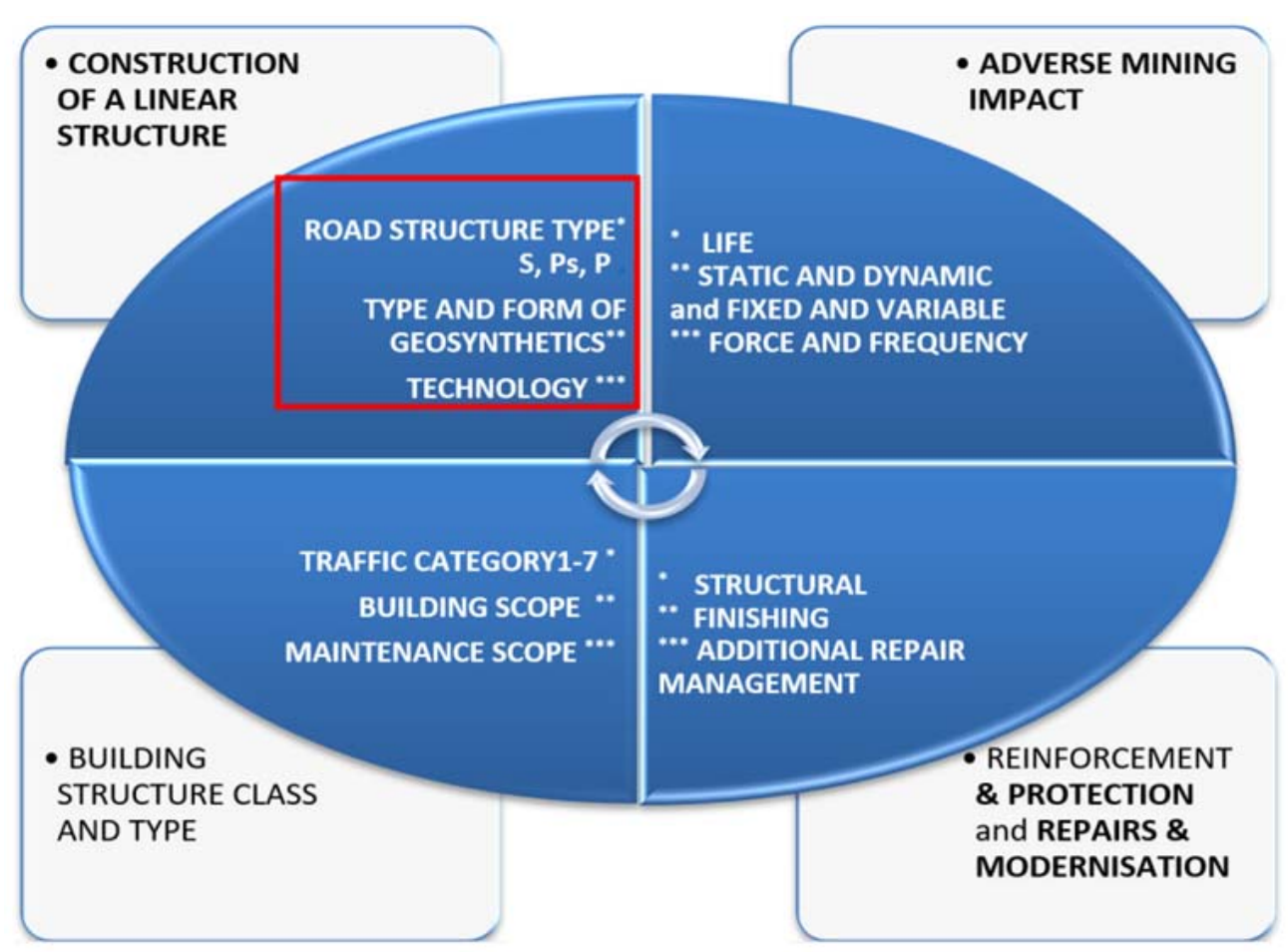

Fig. 3. Scope of analysis of selected variables of the function which describes the real estate with its road structure component in the aspect of investment risk for building or repair and modernisation of roads located in mining impact areas. Four groups of variables were examined, which identified the investment project cost range and the scope of the available range of quality features which affect the estimated valuation (own elaboration) 
The values of the variables are described by values in the ordinal and interval scales, which are then transformed into quality data by means of ranking methods. This paper presents a directional analysis of the data concerning the studied influence of using geotextiles as a building material and structural component of the reference road project. The classified road investment features in the aspect of the presented implementation projects in reference to the main studied property of a geo-synthetic structure revealed relevant results for different sample sizes. The analysed methodology helps to identify the market value of the investment, including the cost of subsoil reinforcement and road structure protection, as well as its repair and modernisation for the analysed geotechnical and mining category of the investment. The total cost specifications were analysed for each of the KR1-KR7 traffic categories for the flexible and rigid surfaces. For the selected optimum group of representative data, each model with specific geo-synthetic materials was analysed as the main variable affecting the investment cost analysis and investment risk value for mining impact Categories II, III and IV (Gwozdz-Lason, 2017a, 2019a). The analysis of the whole model was described with design variables function: implementation, material and cost variables. A specific computational model was analysed as a variable affecting the analysed geo-synthetic material attribute of the proposed structural solution. It included a material variable and investment risk variable which are directly affected by the road investment building material with the impact weight ranging from 22 to $31 \%$.

\section{RESULTS AND DISCUSSION}

The presented models of the structure reinforcement and protection according to the method corresponding to the current BIM strategy (Gwóźdź-Lasoń, 2016a) are used to analyse the cost of building investment design capability in the aspect of all potential variables which can affect the design capability costs and the impact of costs and functional capabilities. The use of the reference linear structure was examined in a set of initial conditions, i.e. zero investment stage (Gwóźdź-Lasoń, 2016b), and under expected mining exploitation impact, previously analysed in detail by the article co-author (Gwozdz-Lason, 2017a, 2017b, 2019a) - Figure 4 . The cost analysis is affected by the investment documentation costs, design costs from concept design through to building and detailed designs, building investment material aspects, implementation of work methods and the total scope of repair and modernisation costs expected during the structure life. The draft schedule of repairs, protection or modernisation

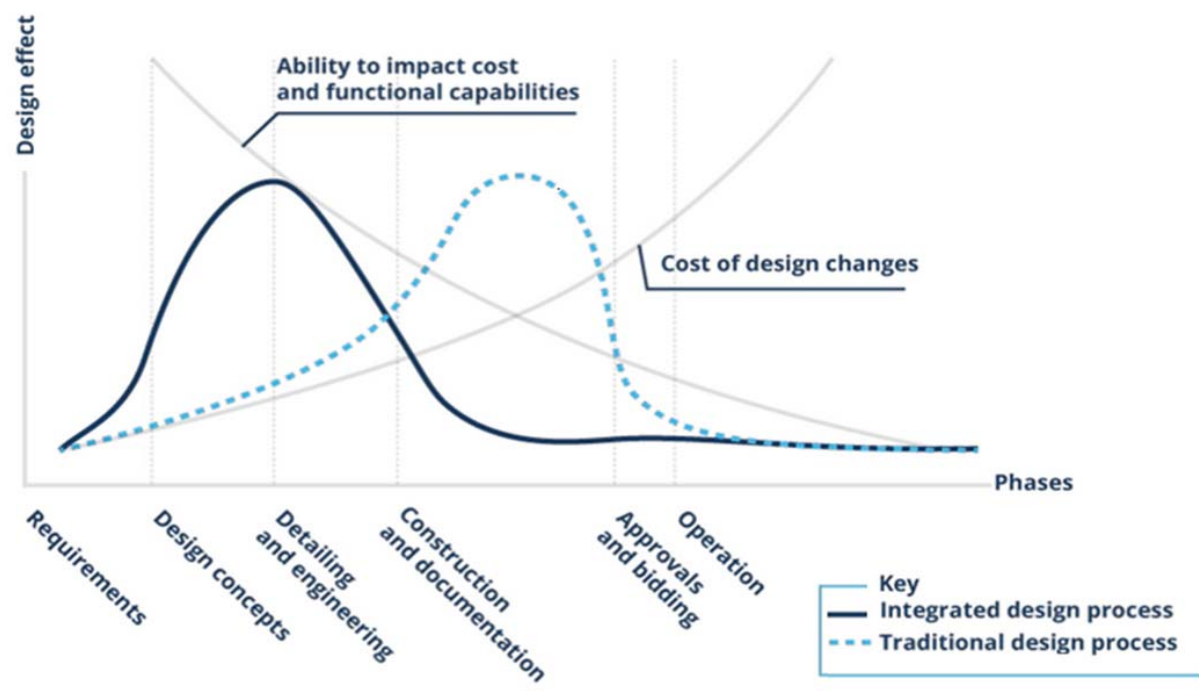

Fig. 4. Analysis of a building investment design and implementation costs in the aspect of structural, functional, material and implementation design changes (MacLeamy, 2004) 
of each structural component for the assumed repair management and for the analysed investment risk on each stage renders very good computational data for the total investment value to be identified.

The main purpose of the results of the performed building cost analyses for each traffic category from KR1 to KR7 for the separated flexible and rigid surfaces was to analyse the impact of the kind and scope of investment implementation technology based on geo-synthetic materials as compared to the scope of classical investment. For the selected group of representative data, individual computational models with specific geo-synthetic materials were analysed. The analysis of the whole model was described with a function of design variables related to implementation, materials and operation. Then all of them were taken for the main analysis as the mean of classical and statistical calculations and only the scope of the variables related to the geo-synthetic material type attribute in a construction solution was analysed (Gwozdz-Lason, 2017a, 2017b). The studied variables revealed a relationship with the investment value, for the assumed level of a specific data group $n_{\min }=13$, and the critical value $\rho(\alpha)$ for $\alpha=0.25$. All analyses reveal that the entire life costs are much lower i.e. the total of design costs, material costs of the analysed geotechnical solution, costs of reinforcement with geo-synthetics, as well as modernisation and repair of a road structure protected and reinforced with geo-synthetics $\left(I_{D G}\right)$. Figure 5 presents the results of statistical analyzes of the total cost of $C V\left(F\left(f_{i}\right)\right)$ in terms of the investment risk factor. The variables of the function determining the size of the risk have been depicted on a histogram, which is the most popular way of presenting the empirical distribution of the examined features - Figure 5A.

The histogram shows the empirical distribution of selected features, i.e. it shows the results for quantitative variables. It answers the questions: at what values are most of the examined results located? is some value most represented in our dataset? or is there an asymmetry in the results? The received answers are the basis for the next step of the analysis. Histograms make it possible to analyze the structure of the analyzed variables and create a new set of representative data. In this case, the main analysis includes variables such as: the type of building material used for the implementation of the road investment $F\left(f_{r m 1}\right)$ and the variables of the scope of investment repairs $F\left(f_{r r 2}\right)$ and modernization $F\left(f_{r m 3}\right)$ and variables of the stages of mining impact $F\left(f_{e g 1}, \ldots, f_{e g n}\right)$. Figure $5 \mathrm{~b}$ shows a box plot for data from a representative set from the surveyed 2017 and 2018. The maximum, minimum, average and median values are displayed. Figure $5 \mathrm{c}$ shows stadardized residuals for a new group of representative data. Studentized residual is the quotient resulting from the division of a residual by an estimate of its standard deviation. It is a form of a Student's t-statistic, with the estimate of error varying between points. Dividing a statistic by a sample standard deviation is called studentizing, in analogy with standardizing and normalizing. A scatter plot using Cartesian coordinates to display values for two variables for a set of data was show on Figure 5d. A scatter plot using Cartesian coordinates to display the values of variables for a dataset is shown in Figure 5d. It presents the values of two-month mean values of the analyzed data after their updating with the calculated weights of the analyzed variables. The displayed values are the results of calculations of the weights of the tested variables and with an indicated range of the calculation error coefficient for the assumed time interval.

Figure 6 clearly presents the total cost of a building project for one investor, showing the costs of a road structure repair and modernisation during the investment life. If the investor is assumed to build and then sell the road, the analysis renders completely different results. Higher costs of design, materials and implementation are evident for the investment option with geo-synthetics, which cannot bring return on investment during the assumed one-year design period, two years for construction and the initial two years of use. That is why the option of a relevant road structure reinforcement design with geo-synthetic materials is not profitable in the investment valuations for short life stages of the structure. The analyses of operating costs and the related repair and modernisation costs for 15-year periods represent the total investment cost on the entirely different level, with completely different $C F$ values for each year. Such an analysis reveals significant profit for the investor as a result of the new design, material and implementation approach. 


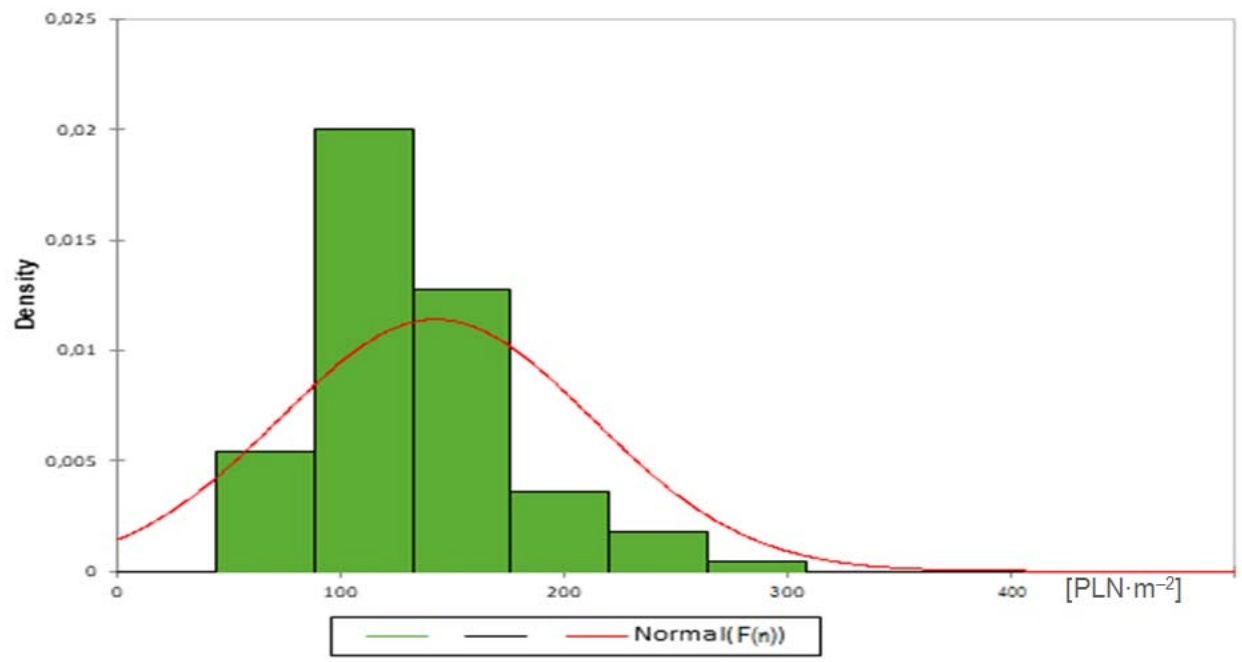

b

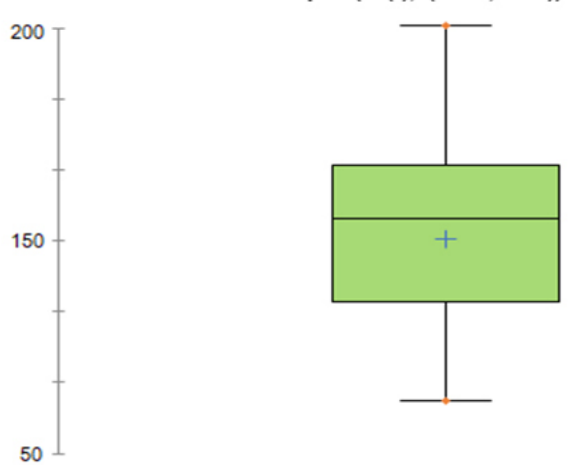

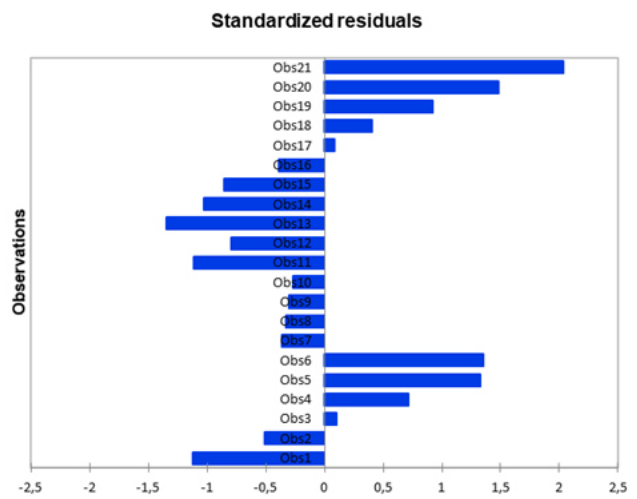

d

Scatter plot(Fn(fi);T(ti))

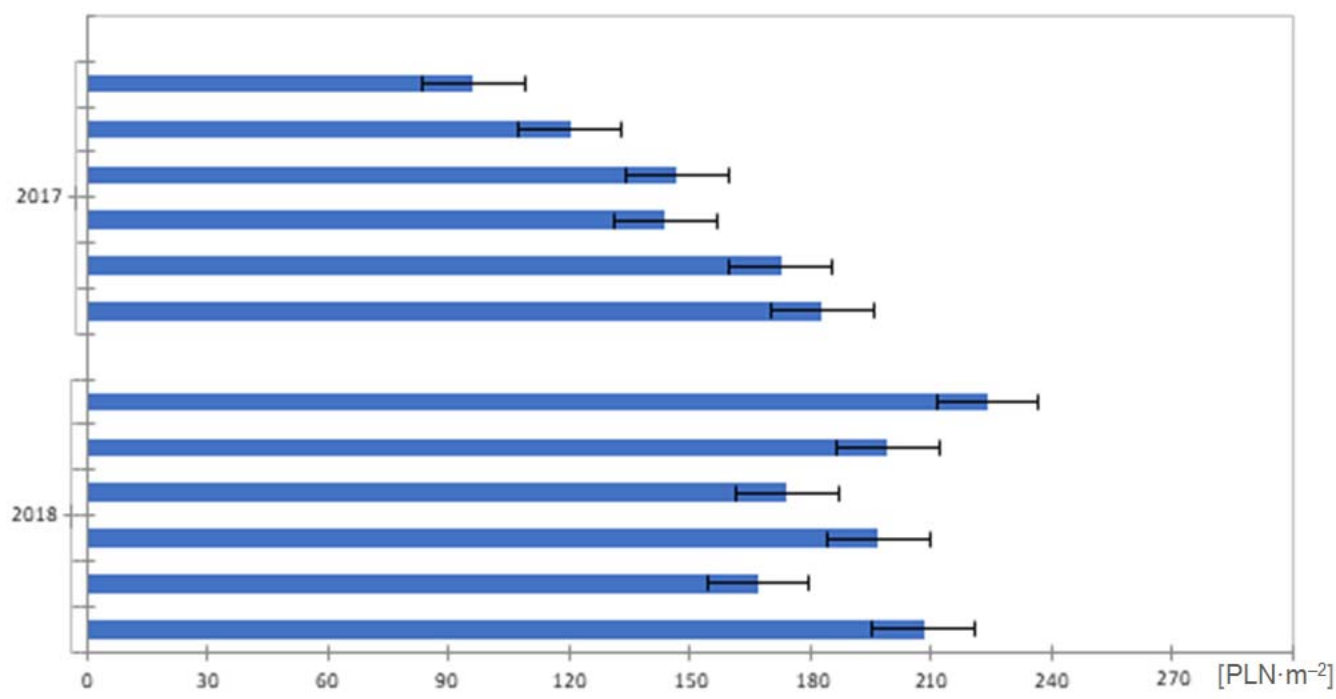

Fig. 5. Analysis of the $C V\left(F\left(f_{i}\right)\right)$ total cost, including the investment risk coefficient, which covers the building material type used for $F\left(f_{r m 1}\right)$ road investment implementation and the variables for the scope of investment repairs $F\left(f_{r r 2}\right)$ and modernisation $F\left(f_{r m 3}\right)$ during its use, including mining impact stages $F\left(f_{\text {eg } 1}, \ldots, f_{\text {egn }}\right)$ : a - histogram; b - box plot for data from a representative set from 2017 and 2018; c - stadardized residuals; $d$ - scatter plot (own elaboration) 


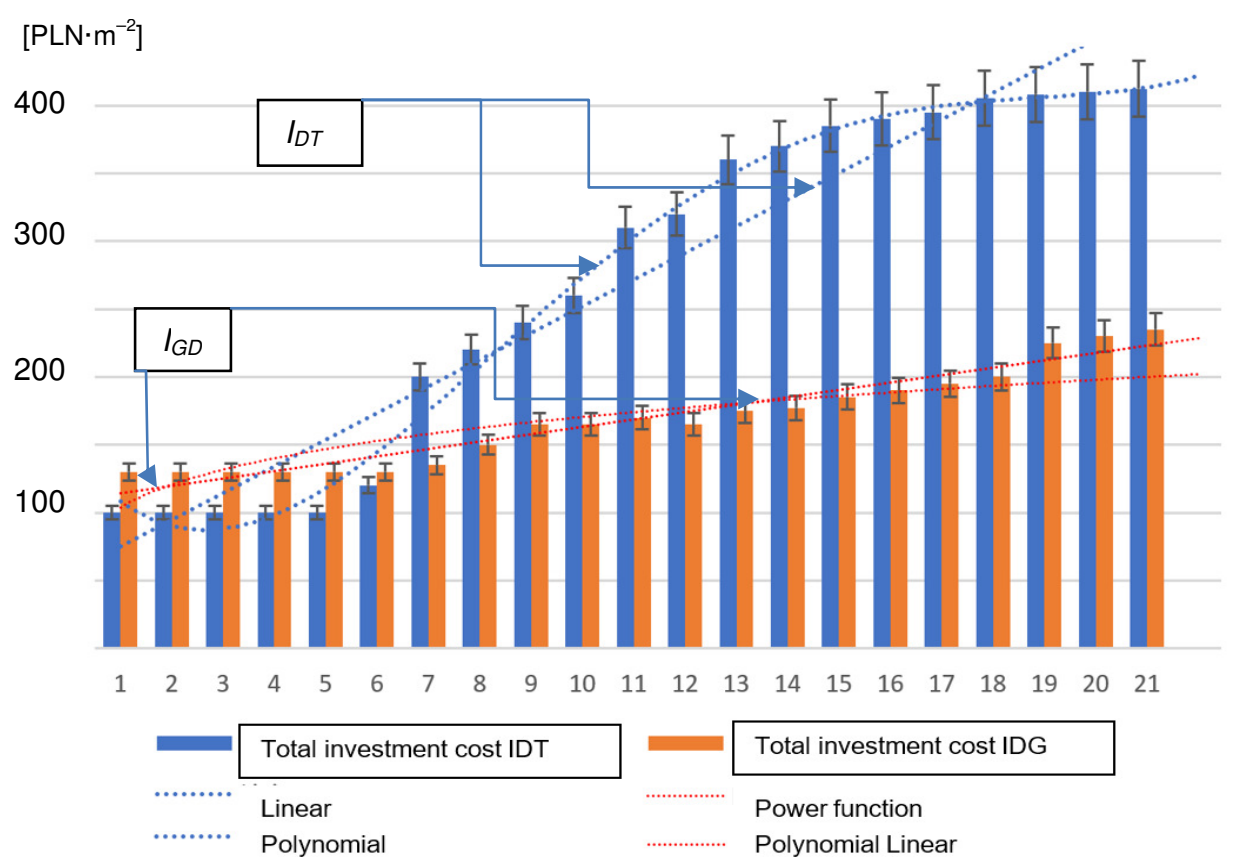

Fig. 6. Total investment cost $\left(I_{D T}\right)$ - traditional and total investment cost $\left(I_{D G}\right)$ - structure with geo-synthetic material; $I_{D T}$ - linear and polynomial analysis, $I_{G D}$ - linear and power function analysis (own elaboration)

The study investigated the econometric model of real estate value from the mixed approach, i.e. to determine the functions of variables for the market value and replacement cost value of a construction investment.

In the analysed stochastic case, the valuation model was used:

$$
C_{c}=X_{M, R} \cdot a+\varepsilon
$$

where:

$C_{C}$ - vector of unit prices of sold real estate,

$X_{M, R}$ - evaluation matrix of selected parameters of market attributes of a market value $f\left(x_{1 M}, \ldots\right.$, $\left.x_{n M}\right)$ and attributes of a replacement character $f\left(x_{1 R}, \ldots, x_{n R}\right)$ dependent on $\left(f_{r m 1}\right), F\left(f_{r r 2}\right)$, $F\left(f_{r m 3}\right)$ and $F\left(f_{e g 1}, \ldots, f_{e g n}\right)$,

$a$ - vector of parameters of the value model,

$\varepsilon-$ vector of residuals in the value model.

The fitted equation is used for prediction market value for road investment structure reinforced. The fitted value is where the values used for explanatory variables correspond to one of the $n$ observations in the data, whereas predicted value is the one obtained for any set of values of explanatory variables. When the values of explanatory variables are the future values of explanatory variables, the predicted values are forecasted values that is wanted.

\section{CONCLUSIONS}

Mining impacts on the land surface have a form of cracks or deformations of building structures. The complexity of the issue of mining deformation impact on road structures requires a comprehensive approach to the evaluation of the surface degradation, including identification of road and mining causes and the design of appropriate protection based on modern materials, including geo-synthetics, with known engineering properties. Complex geotechnical conditions of building the motorways imply the acquisition of specific subsoil and surface reinforcement solutions based on geo-synthetic reinforcement which contributes to improvement in the load capacity and road pavement durability. In order to protect the road pavement structure from revealing the negative effects of 
Kadela, M., Gwóźdź-Lasoń, M. (2021). Economic analysis for technical and executive projects with geosynthetic materials for the protection of linear structures in the mining areas. Acta Sci. Pol. Architectura, 20 (1), 39-49. doi: 10.22630/ASPA.2021.20.1.5

mining impact, geo-synthetic reinforcement is used in two layers: geotextiles at the bottom of asphalt layers and geo-mattresses at the contact plane with the subsoil. Geo-mattresses are designed based on natural and anthropogenic aggregates enclosed with geonet or geotextile. The paper presents sample solutions used in motorways in Poland, including their cost estimation. It was presented that only the analyses of operating costs and the related costs of repairs and modernisations covering a period of 15 years reveal the total cost of road investment on a completely different level and with completely different $\mathrm{CF}$ values for each year. The analysis demonstrates high profit for the investor, of ca. $50 \%$, who benefits from the new design, material and implementation approach.

\section{Authors' contributions}

Conceptualization: M.K.; methodology, validation, formal analysis, investigation: M.K. and M.G.L., writing - original draft preparation: M.K. and M.G.L.; writing - review and editing: M.K. and M.G.L.; visualization: M.G.L.; supervision: M.K.

Both authors have read and agreed to the published version of the manuscript.

\section{REFERENCES}

Dudek, D. \& Kadela, M. (2016). Pull-out strength of resin anchors in non-cracked and cracked concrete and masonry substrates. Procedia Engineering, 161, 864-867.

Dudek, D., Kadela, M. \& Knap, P. (2015). Nośność łączników w podłożach betonowych zarysowanych wskutek oddziaływania eksploatacji górniczej. Bezpieczeństwo Pracy i Ochrona Środowiska w Górnictwie, 10, 23-27.

EKKOM Sp. z o.o. (2014). Rozbudowa węzła Mystowice na autostradzie A4 Katowice-Kraków (unpublished construction design). Kraków.

Fedorowicz, J. (2008). Zagadnienia kontaktowe budowla - podłoże górnicze. Część II. Kryteria tworzenia i oceny modeli obliczeniowych układów konstrukcja budowlana - podłoże górnicze [Building structure - subsoil contact task. Part II. Criteria for modeling-process and analyses carried out for the basic contact tasks building structure - subsoil] (monography). Zeszyty Naukowe. Budownictwo/Politechnika Śląska, 114 (1805).

Fedorowicz, L. (2006). Zagadnienia kontaktowe budowla - podłoże gruntowe. Część I. Kryteria modelowania i analiz podstawowych zagadnień kontaktowych kon- strukcja budowla - podłoże gruntowe [Building structure-subsoil contact task. Part I. Criteria for modelingprocess and analyses carried out for the basic contact tasks building structure-subsoil] (habilitation thesis). Zeszyty Naukowe. Budownictwo/Politechnika Śląska, 107 (1729).

Fedorowicz, L. \& Fedorowicz, J. (2012). Safety assessment of linear structures in areas at risk of large mining deformities. AGH Journal of Mining and Geoengineering, 36 (1), 145-153.

Fedorowicz, L., Fedorowicz, J. \& Kadela, M. (2011). Problemy właściwej interpretacji wyników analiz układów konstrukcja-podłoże gruntów. Górnictwo i Geoinżynieria, 35 (2), 209-216.

Fedorowicz, L. \& Kadela, M. (2012). Model calibration of line construction-subsoil assisted by experimental research. AGH Journal of Mining and Geoengineering, 36 (1), 155-164.

Fedorowicz, L. \& Kadela, M. (2017). Recreation of Small Strains Phenomenon under Pavement Structure and Consequences of Failure to Address It. IOP Conference Series: Materials Science and Engineering, 24 (2), 022005. https://doi.org/10.1088/1757-899X/245/2/022005

Generalna Dyrekcja Dróg Publicznych [GDDP] (2002). Wytyczne do wzmacniania podloża gruntowego $w$ budownictwie drogowym. Warszawa: Instytut Badawczy Dróg i Mostów.

Grygierek, M. \& Kawalec, J. (2017). Selected laboratory research on geogrid impact on stabilization of unbound aggregate layer. Procedia Engineering, 189, 484-491. https://doi.org/10.1016/j.proeng.2017.05.078

Gwóźdź-Lasoń M. (2009). Wykorzystanie numerycznych modeli ośrodka gruntowego i metody rezydualnej do szacowania wartości rynkowej nieruchomości gruntowych o przeznaczeniu komercyjnym [The use of numerical models of reinforced subsoil and the residual method in estimating market value of commercial use properties]. In A. Wawrzynek (Ed.), Wybrane zagadnienia $z$ dziedziny budownictwa: badania naukowe doktorantów (pp. 423-431). Gliwice: Wydawnictwo Politechniki Śląskiej.

Gwozdz-Lason, M. (2010). How to calculate the impact of geotechnical condition plots of land with commercial use on market value this type of real estate In V. P. Petrukhin, V. M. Ulitsky, I. V. Kolybin, M. B. Lisyuk, M. L. Kholmyansky (Eds.), Proceedings of the international geotechnical conference "Geotechnical challenges in megacities" (Vol. 3, pp. 1186-1190). Moscow: NPO Georeconstruction-Fundamentproject (GRF). 
Kadela, M., Gwóźdź-Lasoń, M. (2021). Economic analysis for technical and executive projects with geosynthetic materials for the protection of linear structures in the mining areas. Acta Sci. Pol. Architectura, 20 (1), 39-49. doi: 10.22630/ASPA.2021.20.1.5

Gwóźdź-Lasoń, M. (2010). Numerical models of reinforced subsoil used for estimate the geotechnical parameters impact on market value of plots with commercial use (lecture abstract). In J. Frankovská et al. (Eds.), From research to design in European practice: proceedings of the 14th Danube-European Conference on Geotechnical Engineering, Bratislava, Slovakia, 2nd June - 4th June 2010: key lectures, main lectures and abstracts of papers (p. 271). Bratislava: Slovak University of Technology.

Gwóźdź-Lasoń, M. (2016a). Technologia BIM w projektowaniu geotechnicznym. In A. Urbański (Ed.), Podstawy projektowania geotechnicznego. Wprowadzenie do nowych technologii w geotechnice (pp. 216-230). Kraków: Wydawnictwo Politechniki Krakowskiej.

Gwóźdź-Lasoń, M. (2016b). Badanie i analiza ZEI - zerowego etapu inwestycji określającego nośność podłoża gruntowego jako atrybutu mającego wpływ na wartość całej inwestycji budowlanej i determinującego istotne czynniki wpływające na strategiczne podejmowania decyzji menedżerskich. In K. Pujer (Ed.), Zarządzanie przedsiębiorstwem $w$ zmiennym otoczeniu $w$ kontekście zrównoważonego rozwoju (pp. 179-198). Wrocław: Exante Training \& Consulting.

Gwozdz-Lason, M. (2017a). Analysis by the residual method for estimate market value of land on the areas with mining exploitation in subsoil under future new building. IOP Conference Series: Earth and Environmental Science, 95, 042064. https://doi.org/10.1088/17551315/95/4/042064

Gwozdz-Lason, M. (2017b). The cost-effective and geotechnic safely buildings on the areas with mine exploitation. In 17th International Multidisciplinary Scientific GeoConference (SGEM 2017) (pp. 877-884). Sofia: International Multidisciplinary Scientific GeoConferences (SGEM). https://doi.org/10.5593/sgem2017/13/S03.111

Gwozdz-Lason, M. (2019a). Multiplication analysis of the cause, form and extent of damage to buildings in areas with mining impact. IOP Conference Series: Materials Science and Engineering, 603, 042093. https://doi. org/10.1088/1757-899X/603/4/042093

Gwozdz-Lason, M. (2019b). Effect of active mining impact on properties with engineering structures - forecast and final result discrepancies. IOP Conference Series: Earth and Environmental Science, 221, 012103. https://doi. org/10.1088/1755-1315/221/1/012103

Gwozdz-Lason, M. (2019c). Principles for the application of vibration intensity scale for the prediction and assessment of impact of actions of exploitation mine on buildings and people. IOP Conference Series: Earth and Environmental Science, 221, 012022. https://doi. org/10.1088/1755-1315/221/1/012022
Instytut Badawczy Dróg i Mostów [IBDiM] (2003). Zastosowanie geosyntetyków $w$ budowlach ziemnych. Stadium poznawczo-techniczne (TN/TG-221, zadanie B, etap 2003). Warszawa. Retrieved from: https://www. gddkia.gov.pl/userfiles/articles/p/prace-naukowo-badawcze-zrealizow_3435//documents/tn-tg-221-zastosowanie-geosyntetykw-w-budowlach-ziemnych.pdf

Generalna Dyrekcja Dróg Publicznych \& Instytut Badawczy Dróg i Mostów (2012). Katalog Wzmocnień i Remontów Nawierzchni Podatnych i Pótsztywnych KWRNPP-2012. Warszawa: Instytut Badawczy Dróg i Mostów.

Juraszek, J. (2019). Application of fiber optic FBG techniques in analysis of strain in engineering machines. New Trends in Production Engineering, 2 (1), 480-485.

Juraszek, J. (2020). Fiber Bragg sensors on strain analysis of power transmission lines. Materials, 13 (7), 1559. https://doi.org/10.3390/ma13071559

Kadela, M. (2013). Systemy monitorowania obiektów liniowych na terenach górniczych. In XII Dni Miernictwa Górniczego i Ochrony Terenów Górniczych, Instytut Eksploatacji Złóż, WMiG Politechniki Śląskiej, GKMG GiOŚ ZG SITG, PKMTMG (pp. 163-172). Gliwice: Politechnika Śląska

Kadela, M., Bartoszek, M. \& Fedorowicz, J. (2017). Behaviour of masonry walls under horizontal shear in mining areas. IOP Conference Series: Earth and Environmental Science, 95 (2), 022047. https://doi.org/10.1088/17551315/95/2/022047

Kadela, M. \& Bednarski, Ł. (2014). Wytyczne obserwacji ciągłej obiektów zlokalizowanych na terenach górniczych. Przegląd Górniczy, 70 (8),78-84.

Kadela, M. \& Chomacki, L. (2017). Loads from compressive strain caused by mining activity illustrated with the example of two buildings in Silesia. IOP Conference Series: Materials Science and Engineering, 245 (2), 022004. https://doi.org/10.1088/1757-899X/245/2/022004

Kadela, M. \& Chomacki, L. (2014). Wpływ rodzaju gruntu na stan naprężenia w konstrukcji budynku w obliczu eksploatacji górniczej [Influence of soil type on stresses in the building structure in the light of mining exploitation]. Przeglad Górniczy, 70 (6), 24-29.

Kawalec, J. \& Gryczmański M. (2009). Zastosowania georusztów w geomaterach oraz w konstrukcjach oporowych. In XXIV Ogólnopolskie Warsztaty Pracy Projektanta Konstrukcji, Wisła-Ustroń, 17-20 marca 2009 r. (pp. 83-113). Kraków: Polski Związek Inżynierów i Techników Budownictwa. Oddział Małopolski.

Kawalec, J., Grygierek, M., Koda, E. \& Osiński, P. (2019). Lessons learned on geosynthetics applications in road structures in the Silesia mining region in Poland. 
Kadela, M., Gwóźdź-Lasoń, M. (2021). Economic analysis for technical and executive projects with geosynthetic materials for the protection of linear structures in the mining areas. Acta Sci. Pol. Architectura, 20 (1), 39-49. doi: 10.22630/ASPA.2021.20.1.5

Applied Sciences, 9 (6), 1122. https://doi.org/10.3390/ app9061122

Kwiatek, J. (Ed.) (1997). Ochrona obiektów budowlanych na terenach górniczych. Katowice: Wydawnictwo Głównego Instytutu Górnictwa.

MacLeamy, P. (2004). MacLeamy Curve. Retrieved from http://www.msa-ipd.com/MacleamyCurve.pdf (access 29.09.2015).

McParland, C., Adair, A. \& Mcgreal, S. (2002). Valuation standards: A comparison of four European countries. Journal of Property Investment \& Finance, 20, 127-141.

Miłkowski, A., Pilecki, Z., Kłosek, K. \& Tondera, M. (2010). Autostrada A1 zaprojektowana na „dziurawym” podłożu - cz. 1. Magazyn Autostrady, 3, 104-112.
Myrczek, J., Juraszek, J. \& Tworek, P. (2020). Risk management analysis in construction enterprises in selected regions in Poland. Technical Transactions, 117 (1), 1-13.

Parkasiewicz, B., Kadela, M., Bętkowski, P., Sieńko, R. \& Bednarski, Ł. (2017). Application of structure monitoring systems to the assessment of the behaviour of bridges in mining areas. IOP Conference Series: Materials Science and Engineering, 245 (3), 032018. https:// doi.org/10.1088/1757-899X/245/3/032018

Sieńko, R. (2011). Konstrukcja autostrady Al na obszarze szkód górniczych [Construction of A1 motorway in an area of mining damage]. Magazyn Autostrady, 12, 54-57.

Wu, L. S.-Y., Pai, J. S. \& Hosking, J. R. M. (1996). An algorithm for estimating parameters of state-space models. Statistics \& Probability Letters, 28 (2), 99-106.

\section{ANALIZA EKONOMICZNA DLA PROJEKTÓW TECHNICZNYCH I WYKONAWCZYCH Z MATERIALAMI GEOSYNTETYCZNYMI DO OCHRONY STRUKTUR LINIOWYCH NA OBSZARACH GÓRNICZYCH}

\section{STRESZCZENIE}

W artykule omówiono aspekt projektowy, wykonawczy oraz ekonomiczny inwestycji budowlanych w postaci dróg zlokalizowanych na terenach z oddziaływaniem eksploatacji górniczej. Głównymi diagnozowanymi zmiennymi są elementy materiałowe rozwiązania projektowego, bezpieczeństwo konstrukcji inwestycji drogowej oraz analiza ekonomiczna dla badanych rozwiązań. Omówiono szczegółowo wytyczne projektowe z uwzględnieniem materiałów geosyntetycznych, które spełniają założenia początkowe konstrukcji drogowej w postaci odpowiedniej współpracy z niekorzystnymi górniczymi oddziaływaniami podłoża. Omówione rozwiązania zabezpieczenia i wzmocnienia konstrukcji są przeanalizowane dla II, III i IV kategorii górniczej. Prognostyczną znajomość eksploatacji obiektu drogowego oraz prognozy oddziaływań górniczych według wytycznych materiałowych zużycia technicznego poszczególnych grup geosyntetyków daje model obliczeniowy kosztów całej inwestycji w podejściu ekonometrycznym, które omówione w artykule. Problematyka zagadnienia jest interdyscyplinarna, obejmuje tematykę z budownictwa, procesów stochastycznych, ekonometrii oraz niezawodności danych wyjściowych prognozujących oddziaływania eksploatacyjne kopalń na analizowanych zurbanizowanych terenach komunikacyjnych.

Słowa kluczowe: aspekt ekonomiczny ochrony obiektu, geomaterac, tereny oddziaływania eksploatacji górniczej, nawierzchmia drogowa 